\title{
Ceriara'
}

Jurnal Program Studi Pendidikan Anak Usia Dini

ISSN 2301-9905

Volume 13, No 2 Januari 2021

Fakultas Keguruan dan Ilmu Pendidikan - Universitas Muhammadiyah Tangerang

\section{Hubungan Antara Pola Asuh Orang Tua Dan Kemampuan Berhitung Anak Usia Dini Selama Masa Covid-19 di Kecamatan Pasar Kemis, Tangerang}

\author{
${ }^{1}$ Iman Nurjaman, ${ }^{2}$ Destya Alya Monica \\ 1.2 Program Studi Pendidikan Guru Pendidikan Anak Usia Dini ; Fakultas Keguruan \\ Dan Ilmu Pendidikan ; Universitas Muhammadiyah Tangerang \\ e-mail: 1 Iman.umt@gmail.com, ${ }^{2}$ alyamonica29@gmail.com,
}

\begin{abstract}
Abstrak
Penelitian ini menggunakan jenis penelitian kuantitatif dengan metode survey. Jumlah seluruh populasi adalah 30 orang tua dan 30 guru di Kecamatan Pasar Kemis, Tangerang dengan teknik pengambilan sampel menggunakan NonProbability Sampling. Instrument penelitian yang digunakan adalah penyebaran angket. Instrument pengumpulan data untuk hubungan pola asuh orang tua $(X)$ dan kemampuan berhitung $(Y)$ menggunakan angket skala likert dengan 4 pilihan jawaban. Pengujian hipotesis dilakukan dengan menggunakan rumus korelasi Product Moment, yang diawali dengan uji normalitas dari data yang diperoleh. Berdasarkan hasil penelitian diketahui terdapat hubungan positif yang signifikan hubungan pola asuh orang tua (X) dan kemampuan berhitung (Y) Hal ini terbukti dengan dilakukannya uji regresi linier sederhana yang menghasilkan Fhit untuk uji signifikansi sebesar 2677,26 dan Ftab sebesar 4,20 dengan ketentuan $F_{\text {hit }}>\mathrm{F}_{\text {tab }}$ berarti terdapat hubungan yang signifikan. Dari hasil penelitian ini, dapat disimpulkan bahwa terdapat hubungan antara pola asuh orang tua dengan kemampuan berhitung anak usia dini selama masa covid-19 di Kecamatan Pasar Kemis, Tangerang.
\end{abstract}

Kata Kunci : Kemampuan Berhitung, Pola Asuh Orang Tua

\section{Pengantar}

Pola asuh orang tua merupakan salah satu faktor penting dalam mengembangkan ataupun menghambat pertumbuhan anak. Seorang anak yang dibiasakan dengan suasana keluarga yang terbuka, saling menghargai, saling menerima, dan mendengarkan pendapat anggota keluarga 
lainnya maka ia akan tumbuh menjadi generasi yang terbuka, fleksibel, penuh inisiatif, dan percaya diri. Perilaku kreatif dapat tumbuh dan berkembang dengan baik. Menurut Kohn mengatakan bahwa pola asuh atau pengasuhan merupakan cara orang tua berinteraksi dengan anak yang meliputi pemberian aturan, hadiah, hukuman dan pemberian perhatian, serta tanggapan orang tua terhadap setiap perilaku anak. Kualitas pola asuh yang baik adalah kemampuan orang tua untuk memonitor segala aktivitas anak, sehingga ketika anak dalam keadaan terpuruk orangtua mampu memberikan support dan memperlakukan anak dengan baik, sesuai dengan kondisi anaknya (Monks 2013). Pola asuh mencakup pengasuhan dan juga pendidikan. Orang tua memiliki peranan terpenting dalam kedua hal tersebut, khususnya dimasa pandemi. Aktivitas anak lebih banyak dihabiskan didalam rumah bersama orang tua.

Dalam kondisi saat ini, virus corona bukanlah suatu wabah yang bisa diabaikan begitu saja. Jika dilihat dari gejalanya, orang awam akan mengiranya hanya sebatas influenza biasa, tetapi bagi analisis kedokteran virus ini cukup berbahaya dan mematikan. Saat ini di tahun 2020, perkembangan penularan virus ini cukup signifikan karena penyebarannya sudah mendunia dan seluruh negara merasakan dampaknya termasuk Indonesia. Corona virus adalah sekumpulan virus dari subfamili Orthocronavirinae dalam keluarga Coronaviridae dan ordo Nidovirales. Kelompok virus ini yang dapat menyebabkan penyakit pada burung dan mamalia, termasuk manusia. Pada manusia, coronavirus menyebabkan infeksi saluran pernapasan yang umumnya ringan, seperti pilek, meskipun beberapa bentuk penyakit seperti; SARS, MERS, dan COVID-19 sifatnya lebih mematikan. (Yunus \& Rezki, 2020)

Berdasarkan pengamatan yang telah peneliti lakukan pola asuh orang tua di Kecamatan Pasar Kemis terdapat pola asuh yang lebih dominan yang sudah banyak diterapkan oleh para orang tua yaitu pola asuh demokratis. Misalnya orang tua selalu memberikan kesempatan kepada anak untuk bertanya dan berpendapat, ketika anak mendapat prestasi disekolahnya atau sudah membantu pekerjaan rumah orang tua memberikan apresiasi kepada anak misalnya berupa pujian atau reward. Berdasarkan uraian yang telah dipaparkan diatas, peneliti merasa perlu untuk mengadakan penelitian tentang pola asuh orang tua terhadap kemampuan 
berhitung anak selama masa pandemi covid-19 dan melihat bagaimana kemampuan berhitung anak dirumah bersama orang tua.

\section{Metode}

Metode penelitian merupakan cara ilmiah untuk melakukan sebuah penelitian yang merupakan landasan bagi para peneliti untuk mengambil sebuah keputusan. Penelitian ini dilakukan untuk mengetahui hubungan pola asuh orang tua dan kemampuan berhitung anak selama pandemi covid-19. Penelitian ini menggunakan model penelitian kuantitatif dengan menggunakan survey. Adapun variabel dalam penelitian ini yaitu variabel terikat adalah $\mathrm{Y}$ dan variabel bebas adalah $\mathrm{X}$. Dimana variabel $\mathrm{Y}$ kemampuan berhitung dan variabel $\mathrm{X}$ pola asuh orang tua. Singarimbun (1982:3) dalam metode penelitian survey mengatakan bahwa penelitian survey adalah "penelitian yang mengambil sampel dari satu populasi dan menggunakan kuesioner sebagai alat pengumpulan data yang pokok" Sedangkan menurut Tika (1997:9) mengatakan bahwa "survey adalah suatu metode penelitian yang bertujuan untuk mengumpulkan sejumlah besar data berupa variabel, unit atau individu dalam waktu yang bersamaan, data dikumpulkan melalui individu atau sampel fisik tertentu dengan tujuan agar dapat menggeneralisasikan terhadap apa yang diteliti. Variabel yang dikumpulkan dapat bersifat fisik maupun sosial". Metode pengumpulan angket dalam penelitian ini untuk pengambilan data tentang pola asuh orang tua dan kemampuan berhitung anak.

Tabel 01

Hasil Uji Reliabilitas

\begin{tabular}{llccc}
\hline No & Variabel & ralpha & rkritis & Kriteria \\
\hline 1 & Pola Asuh Orang Tua & 1,102 & 0.600 & Reliabel \\
2 & Kemampuan Berhitung & 1,097 & 0.600 & Reliabel \\
& & & & \\
\hline
\end{tabular}


Berdasarkan uji reliabilitas dilakukan pada item pertanyaan yang dinyatakan valid. Suatu variabel dikatakan reliabel atau handal jika jawaban pertanyaan selalu konsisten. Jadi hasil koefisien reliabilitas instrumen variabel pola asuh orang tua adalah sebesar 1,102, instrumen variabel kemampuan berhitung sebesar 1,097 yang berarti kedua instrumen tersebut dinyatakan reliabel atau memenuhi syarat.

\section{Hasil dan Pembahasan}

Penelitian dilakukan pada seluruh TK, RA, dan KB yang berada diKecamatan Pasar Kemis. Penelitian ini dilakukan dari bulan agustus sampai September 2020. Penelitian ini dilakukan dengan memberikan angket secara online, guru dan orang tua mengisi angket tersebut sesuai dengan pola asuh yang diterapkan dan kemampuan anak. Kemampuan anak dilihat selama anak melakukan kegiatan berhitung dan pola asuh orang tua dilihat pada saat sehari-harinya. Dari hasil penelitian yang telah dilakukan peneliti didapatkan bahwa :

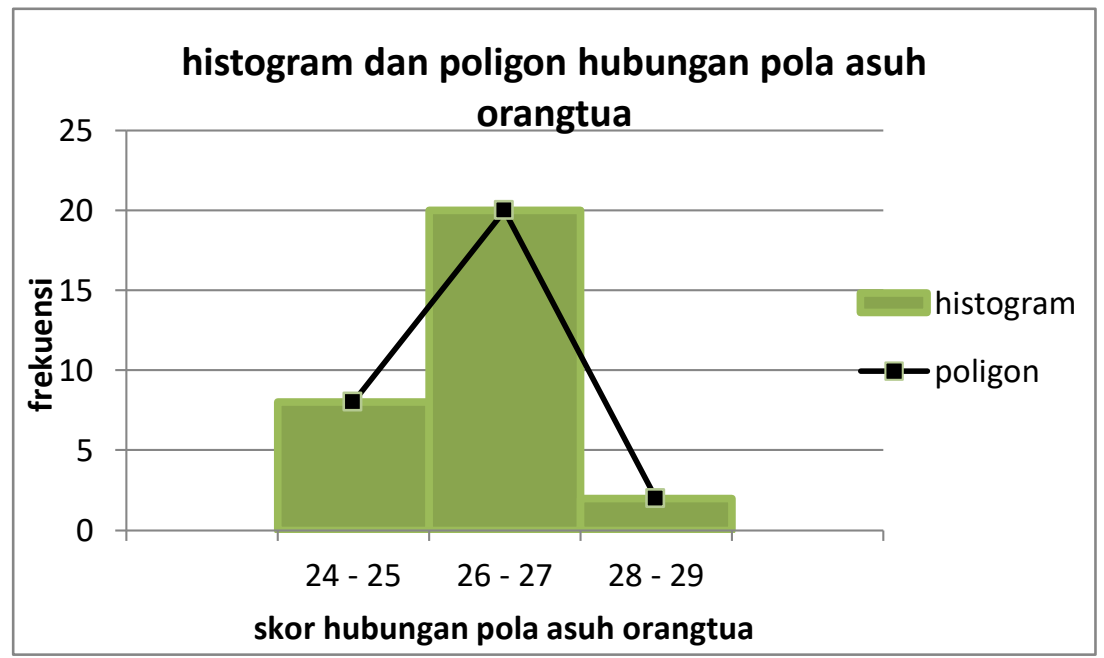

Grafik 1. Data pola asuh orang tua

Berdasarkan gambar di atas, terlihat hanya 7 yang mendapat skor 24-25, sedangkan skor antara 26-27 diperoleh 20, skor 28-29 diperoleh 1 sampel. Dengan demikian dapat dikatakan 
bahwa pola asuh orang tua yang lebih dominan yang dipakai oleh sampel penelitian yaitu pola asuh demokratis

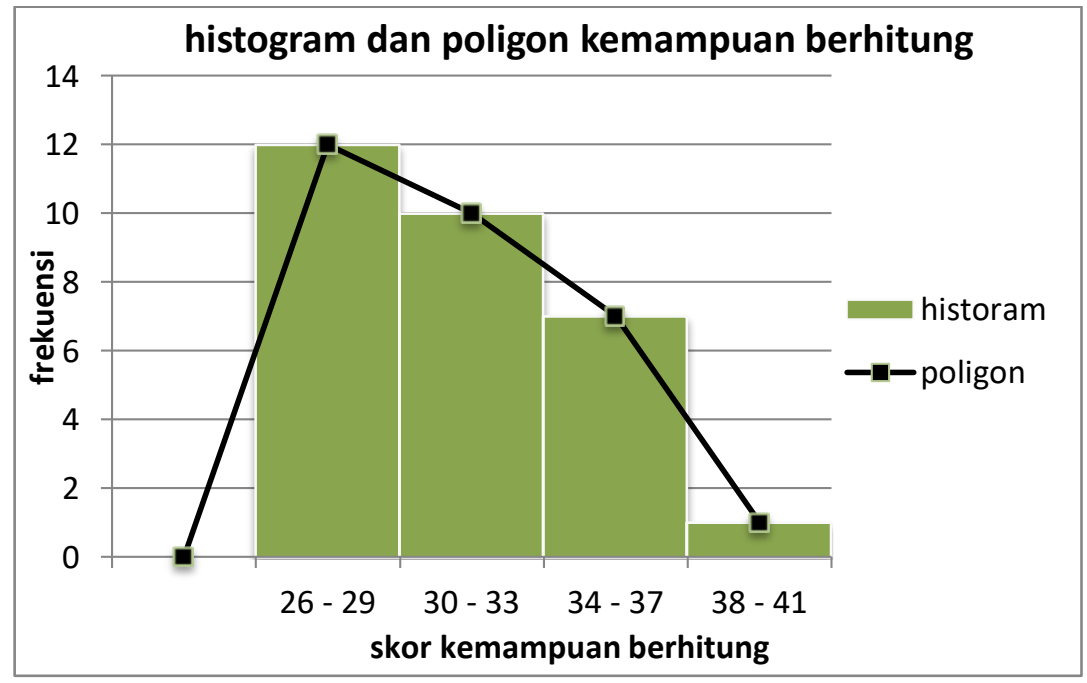

Grafik 2. Data kemampuan berhitung anak

Berdasarkan gambar di atas, terlihat yang mendapat skor 26-29 diperoleh 12 sampel, sedangkan skor antara 30-33 diperoleh 10 sampel, skor 34-37 diperoleh 7 sampel, sementara skor 38-41 diperoleh 1 sampel. Dengan demikian dapat dikatakan bahwa kemampuan berhitung anak rendah karna yang mendapatkan sampel paling banyak pada rentang skor terendah yaitu 26-29.

Tabel 2.

Hasil Analisis Varian (ANOVA) Uji Regresi Linear Sederhana

\begin{tabular}{|c|c|c|c|c|c|c|}
\hline $\begin{array}{c}\text { SUMBER } \\
\text { VARIANS }\end{array}$ & $\mathrm{db}$ & $\mathrm{JK}$ & $\mathrm{RJK}$ & Fhit & $\begin{array}{c}\text { Ftab } \\
(0,05)\end{array}$ & Ket. \\
\hline TOTAL & 30 & 28857 & - & - & - & \\
\hline REGRESI (a) & 1 & 28857 & 28857 & & & \\
$\begin{array}{c}\text { REGRESI (b/a) } \\
\text { SISA }\end{array}$ & 1 & 28520,833 & 28520,833 & 2677,26 & 4,20 & SIGNIKANSI \\
\hline TUNA COCOK & 3 & 298,28378 & 10,652992 & & & \\
GALAT & 25 & 27633,716 & 9211,2387 & $-8,244$ & 2,99 & LINEAR \\
\hline
\end{tabular}


Berdasarkan tabel anova di atas, maka dapat diketahui Fhit untuk uji linieritas sebesar 8,244 dan $F_{\text {tab }}$ sebesar 2,99 dengan ketentuan $F_{\text {hit }}<F_{\text {tab }}$ berarti persamaan regresi liniear. Sedangkan Fhit untuk uji signifikansi sebesar 2677,26 dan $F_{\text {tab }}$ sebesar 4,20 dengan ketentuan Fhit $>F_{\text {tab }}$ berarti terdapat hubungan yang signifikan.

Penelitian ini telah membuktikan terdapat hubungan yang signifikan antara pola asuh orang tua dan kemampuan berhitung anak, namun peneliti menyadari penelitian ini memiliki banyak keterbatasan, antara lain: 1) Saat melakukan penelitian sangat dibatasi kontak langsung dengan narasumber sehingga kurangnya informasi secara menyeluruh 2) Penelitian ini meneliti satu variabel bebas dari sekian banyak variabel yang dapat mempengaruhi kemampuan berhitung anak. 3) Penelitian ini sangat dibatasi kontak secara langsung dengan pihak sekolah sehingga sulit untuk memperoleh data yang diperlukan.

\section{Kesimpulan}

Pengujian hipotesis yang peneliti dapatkan setelah penelitian yaitu data memiliki regresi

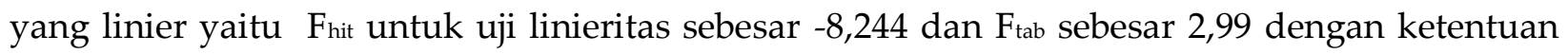
$F_{\text {hit }}<\mathrm{F}_{\text {tab }}$ berarti persamaan regresi liniear. Sedangkan $F_{\text {hit }}$ untuk uji signifikansi sebesar 2677,26 dan $\mathrm{F}_{\text {tab }}$ sebesar 4,20 dengan ketentuan $\mathrm{F}_{\text {hit }}>\mathrm{F}_{\text {tab }}$ berarti terdapat hubungan yang signifikan. Hal tersebut dapat dibuktikan dari hasil analisis varian (ANOVA) uji regresi linear sederhana. Berdasarkan tabel ANOVA tersebut dapat disimpulkan bahwa terdapat hubungan yang signifikan antara pola asuh orang tua dan kemampuan berhitung anak selama pandemi covid19.

\section{Daftar Pustaka}

Amanda, N. ., Antara, P. ., \& Magta, M. (2016). Hubungan Pola Asuh Orangtua dengan Regulasi Diri Anak Usia 5-6 Tahun. Journal Pendidikan Anak Usia Dini Universitas Pendidikan Ganesha, 4(2), 1-11.

Asmiati, D.S., A. C., \& Kusumaningtyas, N. (2018). Hubungan Pola Asuh Orang Tua Dengan 
Jurnal Program Studi Pendidikan Anak Usia Dini

"Ceria"

Konsep Diri Anak Kelompok B Di Tk 1 Pertiwi Semarang. Jurnal Penelitian Dalam Bidang Pendidikan Anak Usia Dini, 7(1), 116-127.

Dubey, S., \& Dkk. (2020). "Psychosocial impact of COVID-19." Diabetes \& Metabolic Syndrome: Clinical Research \& Reviews. https://doi.org/10.1016/j.dsx.2020.05.035

Onyema, E. M., \& dkk. (2020). "Impact of Coronavirus Pandemic on Education." 11(13), 108121. https://doi.org/10.7176/JEP/11-13-12 